\title{
Detection of Rotavirus in Sewage and Creek Water: Efficiency of the Concentration Method
}

\section{DU Mehnert ${ }^{+}$, KE Stewien, CM Hársi, APS Queiroz, JMG Candeias, JAN Candeias}

\author{
Laboratório de Virologia, Departamento de Microbiologia, Instituto de Ciências Biomédicas, Universidade de \\ São Paulo, 05508-900 São Paulo, SP, Brasil
}

Simian rotavirus SA-11, experimentally seeded, was recovered from raw domestic sewage by a twostep concentration procedure, using filtration through a positively charged microporous filter (Zeta Plus 60 S) followed by ultracentrifugation, effecting an 8,000-fold concentration. By this method, a mean recovery of $81 \% \pm 7.5$ of the $S A-11$ virus, was achieved.

Key words: rotavirus - sewage - virus concentration - direct immunoperoxidase

Rotaviruses have been recognized as a major cause of severe infantile gastroenteritis, both in temperate (Kapikian \& Chanock 1990) and in tropical and sub-tropical countries, including Brazil (Linhares et al. 1981, Candeias et al. 1989, Pereira et al. 1993, Stewien et al. 1993). In tropical countries, acute gastroenteritis has accounted for very high morbidity and mortality rates, particularly in poor and malnourished populations living in precarious conditions of water supply and sewage disposal systems (Suttmoller et al. 1982, Trabulsi et al. 1985, Linhares et al. 1986). Several outbreaks of waterborne gastroenteritis with suspected rotavirus etiology have been reported in our country and in other parts of the world (Suttmoller et al. 1982, Hopkins et al. 1984, Linhares et al. 1988).

The presence of rotavirus in the suspected waters have not been determined because of the lack of a suitable method for detecting them at low concentrations (Hejkal et al. 1984). Most methods proposed for the recovery of viruses from sewage and other polluted waters have been developed to detect polio- and other enteroviruses, but they showed low efficiency for rotaviruses (Smith \& Gerba 1982, Hejkal et al. 1984, Rao et al. 1986).

Previously, we presented results of the first longitudinal study conducted in Brazil, which determined the presence and levels of rotaviruses in raw domestic sewage and in sewage-polluted creeks in

\footnotetext{
This work was supported by the Fundação de Amparo à Pesquisa do Estado de São Paulo (FAPESP) - grant 87/ 1820-5.

${ }^{+}$Corresponding author. Fax: +55-11-818.7354.

E-mail: dumehner@biomed.icb2.usp.br

Received 25 April 1996

Accepted 29 September 1996
}

the city of São Paulo (Mehnert \& Stewien 1993). In the present paper we describe in details the twostep concentration procedure used in the study and the efficiency evaluation of this method.

\section{MATERIALS AND METHODS}

Cell cultures - The MA104 continuous line of monkey kidney cells, maintained as previously described (Mehnert \& Stewien 1993), was used for DIP assay.

Simian rotavirus - Simian rotavirus (SA-11), originally obtained from Dr TH Flewett, was grown in MA104 cells maintained with Eagle's MEM, without FBS and supplemented with $10 \mu \mathrm{g} / \mathrm{ml}$ trypsin (1:250 tissue culture grade, Difco Lab., Detroit, MC) as described by Hársi and Candeias (1991).

The SA-11 virus titers were determined by the DIP. In brief, ten-fold dilution of the virus sample was prepared in Eagle's MEM without FBS, supplemented with trypsin $(10 \mu \mathrm{g} / \mathrm{ml})$. Fifty $\mu \mathrm{l}$ volumes of each dilution were added to MA104 cell monolayers, cultured in a 96 well plate in quintuple and incubated for $18 \mathrm{hr}$ at $37^{\circ} \mathrm{C}$. Then, the cells were fixed and rotavirus assayed by DIP (Mehnert \& Stewien 1993). Results are reported as focus forming units (FFU)/50 ml. SA-11 virus was used as a positive control in each assay.

Two-step procedure for concentration of natural occurring rotaviruses in wastewater - Eightliter samples of raw sewage and sewage polluted creek water were collected at three sites in São Paulo (Mehnert \& Stewien 1993). Initially, the $\mathrm{pH}$ was measured and adjusted to 6.5 with $1 \mathrm{~N} \mathrm{HCl}$, if necessary. Then each water sample was passed sequentially through a $140 \mathrm{~mm}$-diameter $\mathrm{AP}_{20}$ filter membrane (porosity of $0.45 \mu \mathrm{m}$, Millipore Corp. Bedford, MA) placed on a Zeta Plus $60 \mathrm{~S}$ microporous positively charged filter (AMF CUNO 
Div., Meridien, CO) in a pressure filter holder (FABBE, São Paulo, Brazil). The flow rate was maintained at $50 \mathrm{ml} / \mathrm{min}$. The filter-bound viruses were eluted with $100 \mathrm{ml}$ of a $3 \%$ Beef-Extract $0.05 \mathrm{M}$ Glycine $\mathrm{pH} 9.0$ solution (BE-GLY). After an exposure of $10 \mathrm{~min}$, the BE-GLY solution was filtered twice and then immediately neutralized with $1 \mathrm{~N} \mathrm{HCl}$. The viruses were reconcentrated by ultracentrifugation at $180,000 \mathrm{x} g$ using a Beckman $70.1 \mathrm{Ti}$ rotor for $2 \mathrm{hr}$ at $4^{\circ} \mathrm{C}$. The sediment was resuspended in $1.0 \mathrm{ml}$ of $0.15 \mathrm{M}$ phosphate buffered saline pH 7.4 (PBS) effecting an 8,000 fold concentration.

The samples were detoxified by mixing it with an equal volume of trichlorotrifluorethano (Freon TF, DuPont) and decontaminated by treatment with antibiotics (1,000 IU Penicillin G and 1,000 $\mu \mathrm{g}$ Streptomycin per $\mathrm{ml})$. All concentrates were stored in aliquots at $-20^{\circ} \mathrm{C}$, until use.

Efficiency of the two-step concentration procedure - Four 8-1 samples of raw domestic sewage were collected at sewage pumping station Edu Chaves at the same day and period to test the efficiency of rotavirus recovery of the concentration method. The wastewater samples were initially autoclaved at $121^{\circ} \mathrm{C}$ for $1 \mathrm{hr}$ and cooled to reach room temperature. Then about $3.5 \times 10^{4} \mathrm{FFU}$ of SA-11/50 $\mu$ l (Table) were inoculated in each water sample and incubated for $30 \mathrm{~min}$ at room temperature with constant magnetic stirring. The rotaviruses were concentrated as described above. Concentrates were then treated with Freon TF and antibiotics and assayed by DIP.

DIP method - DIP was performed as previously described and results expressed as FFU/l (Mehnert \& Stewien 1993).

Fecal coliforms counts - The numbers of fecal coliforms in raw sewage were determined by the membrane filtration technique and the results expressed as colony forming units CFU/l (APHA 1985).

\section{RESULTS}

The ability of the two-step concentration procedure to recover SA-11 from raw domestic sewage was determined in four experiments. Four 8-1 samples of raw domestic sewage were collected uniformly at the same site, day and period. The samples presented a $\mathrm{pH}$ of 6.8 and the mean number of fecal coliforms was $6.4 \times 10^{7} \mathrm{CFU} / \mathrm{l}$.

A SA-11 virus stock suspension with a mean titer of $9.8 \times 10^{6} \mathrm{FFU} / 50 \mathrm{ml}$ was diluted to contain about $3.5 \times 10^{4} \mathrm{FFU} / 50 \mathrm{ml}$ and aliquots of $50 \mathrm{ml}$ of these dilutions were seeded into four sewage samples and concentrated by the two-step procedure (Fig. 1). Rotavirus recovery averaged $81 \% \pm$ 7.5 of the input virus, with a range of $68 \%$ to $88 \%$ in individual trials, as shown in Table.

Rotavirus infected cells are easily recognized by DIP technique at low or medium magnification. The infected cells show dark brown granula around the nuclei as observed on a Carl Zeiss Jena inverted microscope (Fig. 2). Cytotoxic effects were not observed in cell cultures.

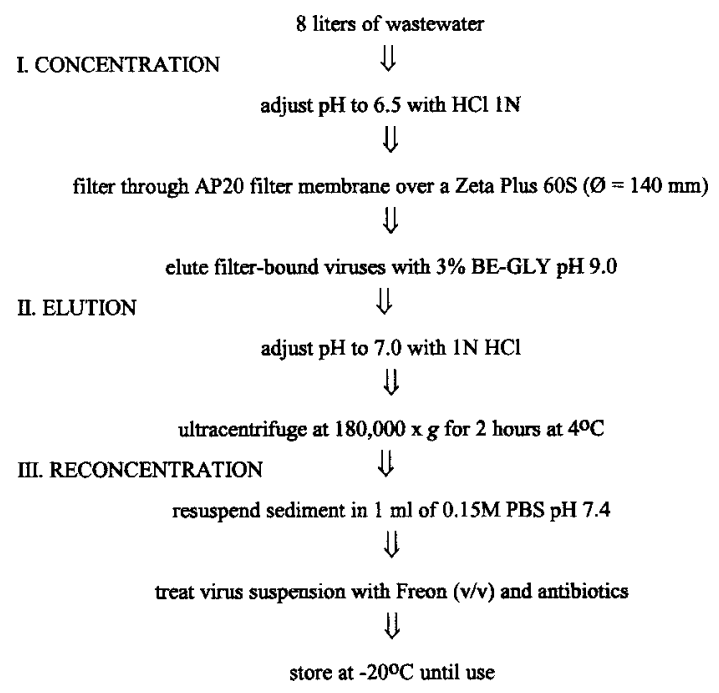

Fig. 1: scheme for concentration of rotavirus from sewage and sewage-polluted creek waters.

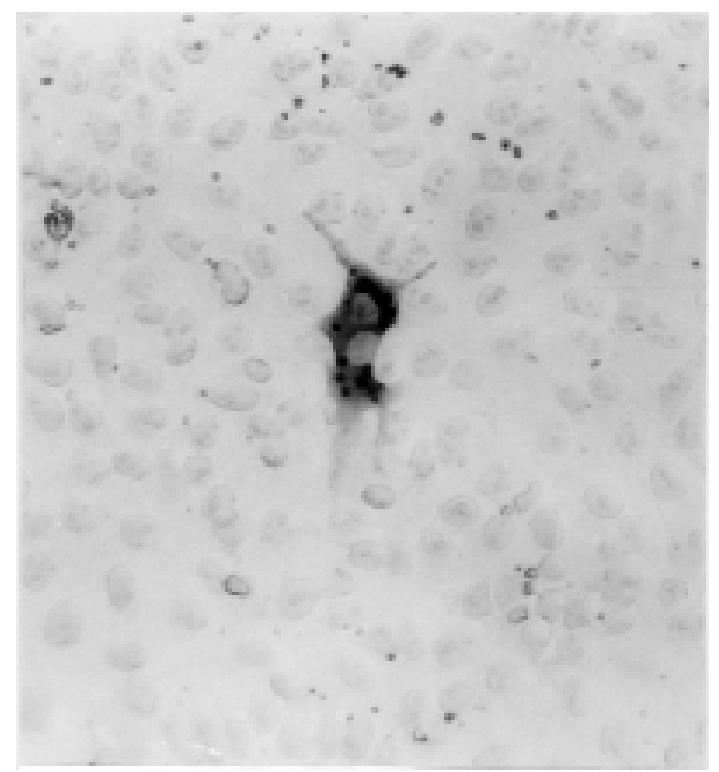

Fig. 2: MA104 cells inoculated with a concentrated water sample and stained by DIP method, showing one focus forming unit of rotavirus. Magnification $400 \mathrm{X}$. 
TABLE

Efficiency of recovery of SA-11 virus from raw sewage water by the two-step concentration procedure

\begin{tabular}{lcccc}
\hline Trial & $\begin{array}{c}\text { Sample } \\
\text { volume } \\
\text { (liter) }\end{array}$ & $\begin{array}{c}\text { Virus } \\
\text { input } \\
(\text { FFU/81) }\end{array}$ & $\begin{array}{c}\text { Virus } \\
\text { recovered } \\
\text { (FFU/81) }\end{array}$ & $\begin{array}{c}\text { \% of virus } \\
\text { recovery }\end{array}$ \\
\hline 1 & 8 & $3.6 \times 10^{4}$ & $3.0 \times 10^{4}$ & 83 \\
2 & 8 & $5.0 \times 10^{4}$ & $3.4 \times 10^{4}$ & 68 \\
3 & 8 & $2.5 \times 10^{4}$ & $2.1 \times 10^{4}$ & 84 \\
4 & 8 & $3.2 \times 10^{4}$ & $2.8 \times 10^{4}$ & 88
\end{tabular}

FFU: focus forming units, as assayed by direct immunoperoxidase.

The mean \pm standard deviation percent efficiency was $81 \pm 7.5$.

\section{DISCUSSION}

Reliable, sensitive and practical methods for detecting small quantities of rotaviruses in sewage and polluted surface waters are needed to determine the public health significance of these pathogens in the environment. In Brazil, about 30 millions people have no access to treated drinking water and only a limited segment of populations in the large cities has an urban sewage system. Otherwise, sewage is discharged into creeks and rivers, specially in the periphery of the cities.

Previous concentration methods for rotaviruses have been effective with SA-11 seeded in tap and estuarine waters (Ramia \& Sattar 1980, GuttmanBass \& Armon 1983, Rao et al. 1986), but they were of limited efficiency for the recovery of these viruses from raw sewage (Smith \& Gerba 1982, Guttman-Bass et al. 1987). In the present study, SA-11 was concentrated efficiently from 8-1 samples of raw domestic sewage by use of a twostep concentration procedure, with a mean recovery of $81 \% \pm 7.5$ (Table).

Adsorption of virus particles on positively charged filter Zeta Plus occurred at neutral $\mathrm{pH}$ range obviating the need for acidification of water samples to $\mathrm{pH}$ 3.0-3.5 when negatively charged filters are used (Sobsey \& Jones 1979, Sobsey \& Glass 1980, Rose et al. 1984). Ultracentrifugation was chosen as a second step after filter elution of virus with BE-GLY at $\mathrm{pH} 9.0$, avoiding other $\mathrm{pH}$ variations, which may result in loss of rotavirus infectivity (Estes et al. 1979).

Since rotavirus levels in sewage and sewagepolluted water seem to be quite different in some countries (Smith \& Gerba 1982, Bosch et al. 1988), the successful detection of these viruses depends on the concentration factor of the procedure. In a longitudinal survey conducted in Jerusalem, Israel, by Guttman-Bass et al. (1987), rotaviruses were not detected, even during the winter months, prob- ably due to the low mean concentration of 287fold attained by the method. Smith and Gerba (1982) detected rotaviruses in raw and secondary treated sewage in Houston after a 400-fold concentration. With the present two-step concentration procedure, achieving an 8,000-fold concentration, Mehnert and Stewien (1993) detect rotaviruses in $29.8 \%$ of the sewage and creek water samples, assaying only volumes of $50 \mu$ l. Higher rates of positivity are to be expected by assaying greater volumes of the wastewater concentrates.

DIP is a simple, cost-effective and reliable technique for detecting rotaviruses in wastewater, because the infected cells are easily recognized with an inverted microscope. Dark brown granula are seen in the cytoplasm around the nucleus, exhibiting a very characteristic picture (Fig. 2). These granula were also observed in infected cell cultures during ultrastructural studies of rotavirus replication (Altenburg et al. 1980, Petrie et al. 1982). A very slight background staining was observed, without interfering in the recognition of the infected cells.

Cytotoxicity of the environmental samples was totally removed in associating the use of Zeta Plus filter to Freon treatment (Hejkal et al. 1982).

Recently, molecular techniques have improved the virus detection in sewage samples, but these methods do not permit the detection of infectious virus particles, which are of great significance in Public Health.

\section{ACKNOWLEDGMENTS}

To Prof. Dr Maria Therezinha Martins for helpful discussions and Prof. Dr Vivian H Pellizari for assistance in fecal coliform determination.

\section{REFERENCES}

Altenburg BC, Grahan DY, Estes MK 1980. Ultrastructural study of rotavirus replication in cultured cells. $J$ Gen Virol 46: 75-85.

APHA - American Public Health Association 1985. Membrane filter technique for members of the coliform group, p. 886-902. In AE Greenberg, RR Trussel \& LS Clesceri (eds). Standard methods for the examination of water and wastewater, 16th ed., American Public Health Association, Washington, D.C.

Bosch A, Pinto RM, Jofre J 1988. Non-seasonal distribution of rotavirus in Barcelona raw sewage. $\mathrm{Zbl}$ Bakt Hyg B 186: 273-277.

Candeias JAN, Rácz ML, Trabulsi LR, Murahowsky J 1989. Relative prevalence of rotavirus diarrhoea in children attending outpatients departments of hospitals and general practitioners in S. Paulo, Brazil. $J$ Diarrhoeal Dis Res 7: 24-27.

Estes MK, Grahan DY, Smith EM, Gerba CP 1979. Rotavirus stability and inactivation. $J$ Gen Virol 43: 403-409. 
Guttman-Bass N, Armon R 1983. Concentration of simian rotavirus SA11 from tap water by membrane filtration and organic flocculation. Appl Environ Microbiol 45: 851-855.

Guttman-Bass N, Tchorsh Y, Marva E 1987. Comparison of methods for rotavirus detection in water and results of a survey of Jerusalem water. Appl Environ Microbiol 53: 761-767.

Hársi CM, Candeias JAN 1991. A reação de imunofluorescência indireta no diagnóstico de rotavírus. Rev Microbiol 22: 282-287.

Hejkal TW, Smith EM, Gerba CP 1982. Reduction of citotoxicity in virus concentrates from environmental samples. Appl Environ Microbiol 43: 731-733.

Hejkal TW, Smith EM, Gerba CP 1984. Seasonal occurrence of rotavirus in sewage. Appl Environ Microbiol 47: 588-590.

Hopkins RS, Gaspard GB, Williams FP, Karlin RJ, Cukor G, Blacklow NR 1984. A community waterborne gastroenteritis outbreak: evidence for rotavirus as the agent. Am J Public Health 74: 263-265.

Kapikian AZ, Chanock RM 1990. Rotaviruses, p. 13531404. In BN Fields \& DM Knipe (eds). Virology. Raven Press, Publishers, New York.

Linhares AC, Gabbay YB, Mascarenhas JDP, Freitas RB, Flewett TH, Beards GM 1988. Epidemiology of rotavirus subgroups and serotypes in Belém, Brazil. Ann Inst Pasteur (Virol) 139: 89-99.

Linhares AC, Pinheiro FP, Freitas RB, Gabbay YB, Shirley JA, Beards GM 1981. An outbreak of rotavirus diarrhea among nonimmune isolated south American Indian community. Am J Epidemiol 113: 703-710.

Linhares AC, Salbé EV, Gabbay YB, Rees N 1986. Prevalence of rotavirus antibody among isolated South American Indian communities. Am J Epidemiol 123: 699-709.

Mehnert DU, Stewien KE 1993. Detection and distribution of rotavirus in raw sewage and creeks in São Paulo, Brazil. Appl Environ Microbiol 59: 140143.

Pereira HG, Linhares AC, Candeias JAN, Glass RI 1993. National Laboratory Surveillance of Viral Agents in Gastroenteritis in Brazil. Bull PAHO 27: 224-233.

Petrie BL, Graham DY, Hanssen H, Estes MK 1982.

Localization of rotavirus antigens in infected cells by ultrastructural immunocytochemistry. J Gen Virol 63: 457-467.

Ramia S, Sattar SA 1980. Concentration of seeded simian SA-11 from potable waters by using talc-celite layers and hydroextraction. Appl Environ Microbiol 39: 493-499.

Rao VC, Metcalf TG, Melnick JL 1986. Development of a method for concentration of rotavirus and its application to recovery of rotavirus from estuarine waters. Appl Environ Microbiol 52: 484-488.

Rose JB, Singh SN, Gerba CP, Kelley LM 1984. Comparison of microporous filters for concentration of viruses from wastewater. Appl Environ Microbiol 47: 989-992.

Smith EM, Gerba CP 1982. Development of a method for detection of rotavirus in water and sewage. Appl Environ Microbiol 43: 1440-1450.

Sobsey MD, Glass JS 1980. Poliovirus concentration from tap water with electropositive adsorbent filters. Appl Environ Microbiol 40: 201-210.

Sobsey MD, Jones BL 1979. Concentration of poliovirus from tap water using positively charged microporous filters. Appl Environ Microbiol 37: 588-595.

Stewien KE, Mós EN, Yanaguita RM, Jerez JA, Durigon EL, Hársi CM, Tanaka H, Moraes RM, Silva LA, Santos MAA, Candeias JMG, Tanaka K, Peret TCT, Baldacci EL, Giglio AE 1993. Viral, bacterial and parasitic pathogens associated with severe diarrhoea in the city of São Paulo, Brazil. J Diarrhoeal Dis Res 11: 148-152.

Suttmoller F, Azeredo RS, Lacerda MD, Barth OM, Pereira HG, Hoffer E, Schatzmayr HG 1982. An outbreak of gastroenteritis caused by both rotavirus and Shigella sonnei in a private school in Rio de Janeiro. J Hyg 88: 285-293.

Trabulsi LR, Toledo MRF, Ceballos BSO, Candeias JAN 1985. Epidemiology of diarrheal diseases in South America, p. 121. In T Tzipori. Infectious diarrhea in the young. Elsevier Biomedical Press, Amsterdam. 